\title{
Secreting clear cell tumour of the parathyroid
}

\author{
Konstantin Bräutigam, ${ }^{\oplus 1}$ Reto Kaderli, ${ }^{2}$ Sabina Berezowska ${ }^{1}$
}

${ }^{1}$ Institute of Pathology, University of Bern, Bern, Switzerland

${ }^{2}$ Department of Visceral Surgery and Medicine, Inselspital University Hospital Bern, Bern, Switzerland

\section{Correspondence to} Dr Konstantin Bräutigam, konstantin.braeutigam@ pathology.unibe.ch

Accepted 29 July 2019
D) Check for updates

(c) BMJ Publishing Group Limited 2019. No commercial re-use. See rights and permissions. Published by BMJ.

To cite: Bräutigam K, Kaderli R, Berezowska S. BMJ Case Rep 2019;12:e231874. doi:10.1136/bcr-2019231874

\section{DESCRIPTION}

A 77-year-old woman presented with the laboratory-based diagnosis of primary hyperparathyroidism. Osteodensitometry showed early stage osteoporosis. 99m Tc-MIBI Single Photon Emission Computed Tomography/Computed Tomography $\left({ }^{99 \mathrm{~m}}\right.$ Tc-MIBI SPECT/CT) and ultrasonography suggested a large adenoma at the inferior pole of the right thyroid lobe.



Figure 1 Histology $(\mathrm{H} \& \mathrm{E}$, original magnification $\times 200)$ demonstrates clear uniform cells with round nuclei and foamy cytoplasm.

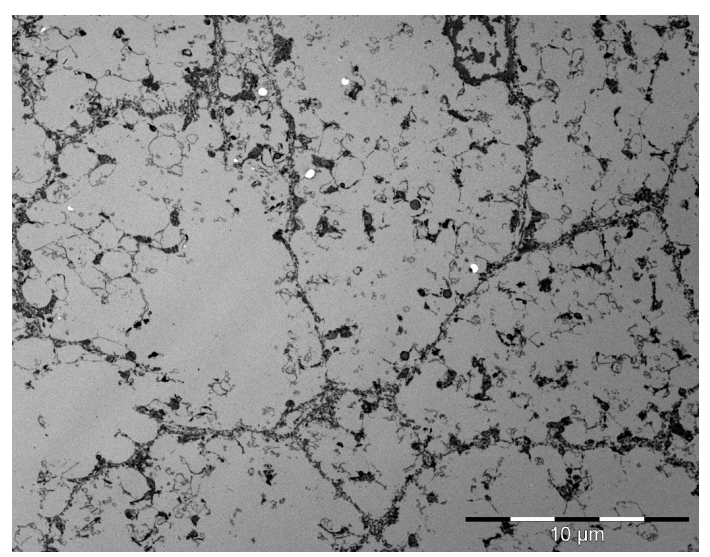

Figure 2 Typical vacuoles shown in transmission electron microscopy.
Parathyroidectomy revealed an encapsulated homogeneous nodule, composed of clear, relatively uniform cells with round nuclei and foamy cytoplasm due to multiple vacuoles (figure 1), most likely representing endoplasmatic reticulum or Golgi apparatus as assessed by transmission electron microscopy (figure 2). Combined with immunohistochemical expression patterns for parathyroidal origin, those finding are typical of water clear cell adenoma, a rare type of parathyroid adenoma and cause of primary hyperparathyroidism with less than 20 cases reported. ${ }^{12}$ Histology (figure 1) strongly resembles metastatic renal cell carcinoma, a true diagnostic pitfall, as it may metastasize to the neck as initial presentation, is notorious for causing late metastases decades after initial tumour removal and may induce hypercalcaemia.

Postoperative parathyroid function was normal.

\section{Learning points}

- Pathologists and clinicians should be aware of water clear cell adenoma, as it is a diagnostic pitfall and may be confused with other clear cell neoplasms, for example, metastatic renal cell carcinoma.

- Water clear cell adenoma is distinctively rare.

Contributors RK has provided the relevant clinical information. $\mathrm{KB}$ and SB implemented the images and pathologic content. All authors wrote and approved the manuscript for publication.

Funding The authors have not declared a specific grant for this research from any funding agency in the public, commercial or not-for-profit sectors.

Competing interests None declared.

Patient consent for publication Obtained.

Provenance and peer review Not commissioned; externally peer reviewed.

\section{REFERENCES}

1 Grenko RT, Anderson KM, Kauffman G, et al. Waterclear cell adenoma of the parathyroid. A case report with immunohistochemistry and electron microscopy. Arch Pathol Lab Med 1995;119:1072-4.

2 Bai S, LiVolsi VA, Fraker DL, et al. Water-clear parathyroid adenoma: report of two cases and literature review. Endocr Pathol 2012;23:196-200. 
Copyright 2019 BMJ Publishing Group. All rights reserved. For permission to reuse any of this content visit https://www.bmj.com/company/products-services/rights-and-licensing/permissions/

BMJ Case Report Fellows may re-use this article for personal use and teaching without any further permission.

Become a Fellow of BMJ Case Reports today and you can:

- Submit as many cases as you like

- Enjoy fast sympathetic peer review and rapid publication of accepted articles

Access all the published articles

Re-use any of the published material for personal use and teaching without further permission

Customer Service

If you have any further queries about your subscription, please contact our customer services team on +44 (0) 2071111105 or via email at support@bmj.com.

Visit casereports.bmj.com for more articles like this and to become a Fellow 